\title{
Biofilter: a promising tool for mitigating methane emission from manure storage
}

\author{
Qiang HUANG*, Qiang ZHANG, Nazim CICEK, Danny MANN \\ Department of Biosystems Engineering, University of Manitoba, Winnipeg R3T 2N2, Canada
}

\begin{abstract}
Liquid manure storage may contribute to methane $\left(\mathrm{CH}_{4}\right)$ emission and this emission can be greatly reduced if appropriate management practices are applied. Biofiltration has been used in other fields for mitigating greenhouse gas (GHG) emission (e.g., landfill) and shown promise for mitigation $\mathrm{CH}_{4}$ emission from liquid manure storage. It has been reported that biofilter was capable of reducing $80 \%$ of $\mathrm{CH}_{4}$ emissions from manure storage. The $\mathrm{CH}_{4}$ removal efficiency is influenced by many factors, including $\mathrm{CH}_{4}$ and $\mathrm{O}_{2}$ concentrations, temperature, moisture, composition of the filter bed, nutrient, and empty bed residency time (EBRT). Biological conversion of methane of a biofilter is a slow process due to the low water solubility of methane. The residence times (EBRT) between $5 \mathrm{~min}$ and $5 \mathrm{~h}$ have been used, whereas a typical EBRT of $25 \mathrm{~s}$ is used for common biofilter applications. Temperature at which methanotrophic bacteria are active ranges from $10^{\circ} \mathrm{C}$ to $45^{\circ} \mathrm{C}$. The maximum activity is found at around $30^{\circ} \mathrm{C}$. The optimal filter bed water content depends on both the gas flow rate and the type of filter bed (soil, compost, etc.) and ranges from $30 \%-70 \%$ of the water holding capacity. Compost is the best material for filter bed. The optimal $\mathrm{pH}$ for methanotrophic bacteria is neutral to slightly acidic. Copper and nitrogen compounds especially nitrate are important nutrients to methanotrophic bacteria but their optimal concentrations have not been founded. Phosphorus and other elements such as potassium and manganese are reported to affect the performance of methanotrophic bacteria but need further confirmation.
\end{abstract}

Keywords: biofilter; greenhouse gas; methane; manure storage

\section{Introduction}

For many countries, agricultural industry is responsible for a significant amount of total greenhouse gases (GHG) emission. In Canada, for example, nitrous oxide $\left(\mathrm{N}_{2} \mathrm{O}\right)$ contributes $61 \%$ of all $\mathrm{N}_{2} \mathrm{O}$ emission, methane $\left(\mathrm{CH}_{4}\right)$ contributes $38 \%$ and carbon dioxide $\left(\mathrm{CO}_{2}\right)$ contributes less than $1 \%$. In the agricultural sector, the main sources of emissions are from the bacterial activity in a ruminant's digestive system (55\%), from soil (24\%) and from manure (21\%) (Massié, 2006). Therefore, manure management is one of primary sources of greenhouse gas (GHG) emissions in the agricultural industry (Cole et al., 1997; Patty et al., 2005). It is possible to reduce methane $\left(\mathrm{CH}_{4}\right)$ emission from manure storage systems by up to $25 \%$ to $80 \%$ using appropriate manure management and treatment practices (Cole et al., 1997).

Many livestock operations, especially for hog and dairy farmers, use liquid manure storage systems. Those liquid manure storage facilities were considered to be responsible for significant portions of the overall $\mathrm{CH}_{4}$ emission from manure storages. In recent years, covering liquid manure storage or manure storage tank is advocated to be an effective way of preventing odor and GHG emission. The beneficial management practices of Manitoba Agriculture states: "Covering liquid manure storage facilities can be an effective way to reduce GHG emissions. Stored manure emits methane $\left(\mathrm{CH}_{4}\right)$, a potent GHG. An impermeable storage cover traps $\mathrm{CH}_{4}$ and prevents its release. The $\mathrm{CH}_{4}$ can be flared off to produce carbon dioxide $\left(\mathrm{CO}_{2}\right)$, a less potent GHG, or used as a source of heat for the farm". Flaring $\mathrm{CH}_{4}$ may require expensive equipment and skills to operate. Additionally the $\mathrm{CH}_{4}$ content of the emitted gas needs to be high enough to allow effective combustion. An alternative is using biofiltration (biofilters). A biofilter uses microorganisms (bacteria)

Received 2010-09-07, accepted 2010-10-09

doi: 10.3724/SP.J.1227.2011.00061

* Corresponding author: Qiang HUANG (E-mail: Qiangh@cc.umanitoba.ca) 
to break down various compounds in the air when the air passes the biofilter media. The bacterial oxidation of methane is a common phenomenon that occurs in nature, such as tropical forest, grassland; landfills cover soil, peatland, and rice paddy soil. Removing methane by biofiltration is basically aerobic conversion of methane to carbon dioxide $\left(\mathrm{CO}_{2}\right)$ and water by methanotrophic (methane consuming) bacteria grown in the biofilter media. Despite the vast body of literature detailing the oxidation of methane in natural environments, relatively little research has been conducted on the application of methane biofilters for manure storage emissions (Massé, 2006). This paper summarizes the information on the use of biofilters in mitigating GHG emissions, assesses the technical feasibility of using biofilters in mitigating GHG emissions from covered hog manure storage based on the literature review.

\section{The release rate of methane from liq- uid manure storage}

For covered liquid manure storages, methane concentration in the headspace depends on air exchanges between the headspace and outside air. In theory, at an air-exchange rate of zero, the headspace concentration equals to undiluted biogas that contains about 425 $\mathrm{g} / \mathrm{m}^{3}(65 \%, \mathrm{v} / \mathrm{v})$ methane (Safley and Westerman, 1988, 1989; DeSutter and Ham, 2005). In practice, however, the cover contains some openings that permit ventilation that results in methane concentrations ranging from $0.1 \mathrm{~g} / \mathrm{m}^{3}$ to $20 \mathrm{~g} / \mathrm{m}^{3}(0-3 \%)$ (Roland et al., 2005).

The published gas fluxes varied greatly and were expressed in various units. For the data expressed in volumetric flux unit, the measured fluxes of $\mathrm{CH}_{4}$ ranged from 0.0007 to $0.64 \mathrm{~m}^{3} /\left(\mathrm{m}^{2} \cdot\right.$ day $)$. For studies that expressed flux results on weight-based units, the measured fluxes ranged from 0.2 to $202.74 \mathrm{~g} /\left(\mathrm{m}^{2}\right.$.day). The measured fluxes usually have great spatial, daily, and seasonal variations (Safley and Westerman, 1988; DeSutter and Ham, 2005). Spatial variation was observed both within the same liquid manure storage and among storages and was closely related to substrate distribution (Safley and Westerman, 1988; WagnerRiddle et al., 2006). Greater $\mathrm{CH}_{4}$ flux was observed near inlet portion of storages, where more manure was distributed than in other places. The flux variation observed among several storages in one area was a result of loading rate differences among storages (Safley and Westerman, 1988). Higher loading rates often resulted in higher biological activity and therefore higher gas flux.

The flux of biogas from storages showed both daily and seasonal variations. Higher flux rates were usually observed during the day and summer, while lower flux rates were observed during the night and winter (Sharpe and Harper, 1999). The daily and seasonal variations in biogas emission rates resulted from storage temperature and wind speed variations. Higher temperature and wind speed during the day and summer would result in higher emission rates, and lower temperature and wind speed during the night and winter would result in lower emission rates (Sharpe and Harper, 1999). However, the pattern of seasonal flux variation might be altered by substrate availability for methanogenesis. DeSutter and Ham (2005) found the highest emission rate in spring, which declined during summer due to substrate limitation. The peak emission rate occurred in early June and nearly $50 \%$ of annual gas losses occurred within 30 days.

\section{The principles of biofiltration}

Biofiltration uses microorganisms to degrade and oxidize gaseous pollutants to un-harmful gases. This technique has been used for reducing odors, hydrogen sulfide and ammonia emissions from farms (Massé, 2006). It has also been employed to treat air streams contaminated with many harmful gases (Tahraoui and Denis Rho, 1998; Li et al., 2002; Yoon and Park, 2002). However, the application of bio-filtration in the treatment of $\mathrm{CH}_{4}$ is relatively new. The experiment conducted by Massé (2006) indicated that biofiltration is one of the promising techniques capable of reducing GHG emissions from livestock operations, particularly methane.

Methane biofilters use methanotrophs living in porous media to oxidize $\mathrm{CH}_{4}$ to $\mathrm{CO}_{2}$. Methanotrophic bacteria (or methanotrophs) use methane as their energy and carbon source whereby methane is degraded to carbon dioxide and water (Hanson and Hanson, 1996). Methane oxidation by methanotrophs occurs in natural environments and can be found in many natu- 
ral aerobic anaerobic interfaces. For example, methane oxidation has been reported in tropical forests, grasslands and meadows, landfill cover soils, deserts, and agricultural soils (Nikiema et al., 2007).

A man-made biofilter is designed and constructed with the goal of exerting maximum efficiency for gas treatment. A good biofilter is a three-phase bioreactor: the filter bed constitutes the solid phase, the biofilm the liquid phase and the gaseous pollutants the gas phase (Nikiema et al., 2007). The solid biofiltration media and the liquid phase offer microorganisms' surface for immobilization, nutrients and water for growth, and the space for gas exchange. The gaseous phase offers microorganism the necessary gases $\left(\mathrm{CH}_{4}\right.$ and $\mathrm{O}_{2}$ for methane biofilter) for their survival. Therefore, biofilters favor some specific microorganisms' activities.

According to the way that gases circulate in the biofilter, the biofilter can be classified as a closed system or open system (Nikiema et al., 2007). The majority of biofilters, as used in lab-scale experiments, are closed systems, in which air supply is ensured by a forced ventilation system. Gas circulation in the biofilter can be from either top to bottom or conversely. In a closed biofilter, maintaining steady operational parameters is also a relatively easy, resulting in good performance. Nikiema et al. (2007) summarized the performance of biofilters used for mitigation of $\mathrm{CH}_{4}$ emission from landfills and reported methane conversion values as high as $90 \%$.

Open systems are mostly found in landfill sites. In this case, the flow of the polluted gas in the bed proceeds upwards, while the $\mathrm{O}_{2}$ diffuses from the ambient air into the bed (passive ventilation) (Nikiema et al., 2007). The open system is difficulty in controlling the operational parameters, such as temperature and moisture levels. Moreover, the transfer of $\mathrm{O}_{2}$ to the bed's lowest layers limits the performance of open system (Kjeldsen et al., 1997; Gebert et al., 2001). For example, an open biofilter installed on a landfill site only had a removal efficiencies of up to $60 \%$ if the empty bed residence times (EBRT) was at least an hour (Du Plessis et al., 2003; Gebert and Groengroeft, 2006a, b).

A biofilter should have at least $1 \mathrm{~m}^{3}$ of filter bed for achieving flow rates of $\mathrm{CH}_{4}$ in the range of 0.01-2.5 $\mathrm{m}^{3} / \mathrm{h}$ (Straka et al., 1999; Streese and Stegmann, 2003;
Haubrichs and Widmann, 2006). The height of the open biofilters with passive ventilation, used for $\mathrm{CH}_{4}$ elimination, must also be lower than $1 \mathrm{~m}$ (Kjeldsen et al., 1997; Boeckx and Van Cleemput, 2000; Stein and Hettiaratchi, 2001). Open systems are usually less expensive (by at least $15 \%$ ) than closed systems.

\section{Microorganisms}

\subsection{Methanotrophs}

Three basic steps were indentified in the process of decomposing $\mathrm{CH}_{4}$ by methanotrophs. The first step is the oxidation of $\mathrm{CH}_{4}$ to methanol through utilizing the enzyme methane monooxygenase, MMO (Hanson and Hanson, 1996; Auman and Lidstrom, 2002). Then the methanol is further transformed into formaldehyde. In the final step, formaldehyde produced from the previous step is used in a dissimilatory pathway (i.e. being oxidized to $\mathrm{CO}_{2}$, with formate as an intermediate) or via several types of assimilatory pathways, leading to the synthesis of cell components, which is necessary for the growth of methanotrophs (Hanson and Hanson, 1996).

Generally, the specific bacteria responsible for the decomposition of $\mathrm{CH}_{4}$ are named as methanotrophs. However, depending on their roles in the $\mathrm{CH}_{4}$ decomposition process, the genera of methanotrophs are grouped into three main types: type I, type II, and type $\mathrm{X}$. Type I methanotrophs assimilate formaldehyde by the ribulose monophosphate pathway and their cellular membranes are mainly made up of fatty acids with 16 , or sometimes 14 atoms of carbon (Nikiema et al., 2007). Type II methanotrophs assimilate formaldehyde through the serine pathway and their cellular membranes contain fatty acids of 18 carbons. Type X has both properties of types I and II. Its cellular membranes fatty acids have 16 carbons and the assimilation of formaldehyde is through both the ribulose monophosphate cycle and the serine pathway (Nikiema et al., 2007).

\subsection{Methane monooxygenase enzyme (MMO)}

A specific enzyme known as methane monooxygenase or MMO was reported to be the key enzyme allowing methanotrophs to perform the decomposition of $\mathrm{CH}_{4}$ (Hanson and Hanson, 1996). This enzyme exists in two forms: particulate MMO (pMMO) and soluble 
MMO (sMMO). The pMMO enzyme can be found in and synthesized by all methanotrophs, except Methylocella, but the sMMO is almost always present in bacteria of types II and X. Methanotrophs containing pMMO grow more rapidly than those having the sMMO (types II and X) (Nikiema et al., 2007).

\subsection{Other bacteria}

In addition to methanotrophs, some other bacteria can also decompose $\mathrm{CH}_{4}$ under some situations. For example, nitrifying bacteria, that are responsible for the decomposition of ammonia $\left(\mathrm{NH}_{3}\right)$, can also degrade $\mathrm{CH}_{4}$. However, their performance rate is less than 5\% of the pure methanotrophic populations (Hanson and Hanson, 1996; Bodelier and Frenzel, 1999). Also, some bacteria involved in the decomposition of methanol are capable of degrading $\mathrm{CH}_{4}$ if the $\mathrm{CH}_{4}$ concentrations remain below $10 \%(\mathrm{v} / \mathrm{v})$.

\section{The performance of methane biofilters}

The performance of a methane biofilter is measured by a removal efficiency parameter as defined in the following equation:

$$
\text { Removal Efficiency: } R E=\frac{C_{\text {in }}-C_{\text {out }}}{C_{\text {in }}} \times 100 \text {, }
$$

where, $C_{\text {in }}$ is the methane concentration of the gas at the inlet of the biofilter in ppm, and $C_{\text {out }}$ is the methane concentration of the gas at the outlet of the biofilter in ppm. This Removal Efficiency was sometimes given different names, Conversion $(X)$, for example (Nikiema et al. 2007). Elimination capacity (EC) is another parameter that can be used to access the performance of a biofilter. It was calculated using the following equation:

$$
E C=I L \times \frac{X}{100},
$$

where $E C$ is elimination capacity $\left(\mathrm{g} /\left(\mathrm{m}^{2} \cdot \mathrm{d}\right)\right.$ or $\mathrm{g} /\left(\mathrm{m}^{3} \cdot \mathrm{d}\right)$; $I L$ is the inlet load $\left(\mathrm{g} /\left(\mathrm{m}^{3} \cdot \mathrm{d}\right)\right)$; and $X$ is Conversion (\%). The inlet load (IL) is calculated according to the following equation:

$$
I L=\frac{C_{\text {in }} \times Q}{S},
$$

where $C_{i n}$ is the $\mathrm{CH}_{4}$ concentration of the biogas flowing into the methane biofilter in $\mathrm{g} / \mathrm{m}^{3} ; Q$ is the flow rate of the biogas in $\mathrm{m}^{3} / \mathrm{d}$; and $S$ is the biofilter bed cross section in $\mathrm{m}^{2}$.
The performance of methane biofilters depends on various factors, including the biofilter type, the empty bed residence time (EBRT), and operating conditions. In mitigating $\mathrm{CH}_{4}$ emissions from landfill sites, the closed biofilter was reported to show good performance, with $\mathrm{CH}_{4} \mathrm{X}$-values as high as $90 \%$ (Dammann et al., 1999; Gebert et al., 2001; Streese et al., 2001; Du Plessis et al., 2003; Nikiema et al., 2005), in contrast to a X-value of $60 \%$ that was obtained from the open methane biofilter with an EBRT of at least an hour (Du Plessis et al., 2003; Gebert and Groengroeft, 2006a, b). The best EC obtained with a laboratory-scale closed biofilter was in the range of 325$400 \mathrm{~g} /\left(\mathrm{m}^{2} \cdot \mathrm{d}\right)($ Hettiaratchi and Stein, 2001). In general, the biofilter eliminates some $10 \%-100 \%$ of the $\mathrm{CH}_{4}$ escaping from the upper layers of landfills, depending on local climatic conditions (Nozhevnikova et al., 1993; Kightley et al., 1995; Czepiel et al., 1996).

Compared with many cases of biofilters used for mitigating $\mathrm{CH}_{4}$ emission from landfill sites, few cases were reported for using biofilters for mitigating $\mathrm{CH}_{4}$ emission from manure storages. Masse (2007) reported that the removal efficiency reached up to $80 \%$ for the four types of media material used in the biofilter. This technology was identified as a promising method for controlling methane emissions from manure storages. Venugopal et al. (2003) conducted a lab-scale experiment using a methane biofilter for mitigating $\mathrm{CH}_{4}$ emission from a gas meter station. They report that the conversion varied with temperature, reaching $90 \%$ during the summer and dropping to $20 \%$ during the winter. Melse et al. (2005) reported a $\mathrm{CH}_{4}$ removal rate up to $85 \%$ in a lab-scale biofilter used in the mitigation of $\mathrm{CH}_{4}$ emissions from a liquid manure storage.

\section{Factors affecting the efficiency of a methane biofilter}

\subsection{Oxygen, methane, and carbon concentrations}

Methane degradation by methanotrophs requires $\mathrm{CH}_{4}$ and $\mathrm{O}_{2}$ as substrates. In fact, methanotrophs can be found in small quantities in any environment exposed simultaneously to significant amounts of $\mathrm{CH}_{4}$ and $\mathrm{O}_{2}$ (Borjesson et al., 1998; Dammann et al., 1999). However, the optimal concentrations of $\mathrm{CH}_{4}$ and $\mathrm{O}_{2}$ for $\mathrm{CH}_{4}$ degradation have not been determined. Lit- 
eratures showed a variation in $\mathrm{CH}_{4}$ and $\mathrm{O}_{2}$ optimal concentrations. It was reported that type I bacteria grew better in an environment with $\mathrm{O}_{2}$ concentration of $21 \%(\mathrm{v} / \mathrm{v})$, associated with a $\mathrm{CH}_{4}$ concentration less than $1,000 \mathrm{ppm}$, while type II bacteria develop better in an environment with $\mathrm{CH}_{4}$ concentration above $1 \%$ $(\mathrm{v} / \mathrm{v})$ and $\mathrm{O}_{2}$ concentration at about $1 \%(\mathrm{v} / \mathrm{v})$ (Hanson and Hanson, 1996; Henckel et al., 2000). However, some type I bacteria have their growth stimulated only in the presence of an appreciable concentration of $\mathrm{CH}_{4}$ $(>1 \%, \mathrm{v} / \mathrm{v})$, and correspondingly, a low amount of $\mathrm{O}_{2}$ $(<1 \%$, v/v) (Henckel et al., 2000; Erwin et al., 2005). Bender and Conrad (1994), Czepiel et al. (1996) and Stein and Hettiaratchi (2001) have shown that, by increasing the $\mathrm{O}_{2}$ concentration from $3 \%$ to $20 \%(\mathrm{v} / \mathrm{v})$ in the gas mixture, the $\mathrm{CH}_{4}$ conversion varies only slightly (less than 10\%). However, a decrease of $\mathrm{O}_{2}$ concentrations from $3 \%$ to $1 \%$ causes a decrease of $\mathrm{CH}_{4}$ oxidation of more than $50 \%$. In the experiments of Stein and Hettiaratchi (2001), maximal $\mathrm{CH}_{4}$ elimination was obtained at $\mathrm{O}_{2}$ concentrations between $0.75 \%$ and $1.6 \%$. The presence of $\mathrm{CO}_{2}$ in a biofilter modifies the behavior of the microorganisms. Acha et al. (2002) reported that the activity of the methanotrophs, using the serine pathway for the assimilation of formaldehyde obtained during the decomposition process of $\mathrm{CH}_{4}$, requires some $\mathrm{CO}_{2}$ input (partial pressure of $\mathrm{CO}_{2}$ around $11.6 \mathrm{kPa}$ ).

\subsection{Temperature}

The temperature in which methanotrophic bacteria are active ranges from $10^{\circ} \mathrm{C}$ to $45^{\circ} \mathrm{C}$. The maximum activity was found at around $30^{\circ} \mathrm{C}$ (Whalen et al., 1990; Bender and Conard, 1994; Boeckx and Cleemput, 1996). However Priemé and Christensen (1997) observed methane oxidation to be active in temperatures as low as $1^{\circ} \mathrm{C}$ in the field and $2^{\circ} \mathrm{C}$ in soil cores experiments. King and Adamsen (1992) observed methane consumption at $-1^{\circ} \mathrm{C}$ and they suggested that methane consumption might occur at low temperatures as long as the soil water remains liquid. Summerfield et al. (1993) showed that the soil microflora was active even when the soil was covered by snow and near $0^{\circ} \mathrm{C}$, and that methane consumption was taking place under these conditions.

It was reported that the conversion $(X)$ fell by around $50 \%$ when the temperature was reduced from $30^{\circ} \mathrm{C}$ to $20^{\circ} \mathrm{C}$ or from $29^{\circ} \mathrm{C}$ to $24^{\circ} \mathrm{C}$ (Dammann et al.,
1999; Streese et al., 2001). Between $-5^{\circ} \mathrm{C}$ and $10^{\circ} \mathrm{C}$ of ambient temperature, the biological elimination of $\mathrm{CH}_{4}$ in an open biofilter system (landfill cover soil) considerably decreased, i.e. more than $80 \%$, compared with the value at $15^{\circ} \mathrm{C}$ (Christophersen et al., 2000; Le Mer and Roger, 2001).

\subsection{Moisture content}

The optimum moisture content varies depend on what kind of material used to build biofilter. It ranges from $30 \%-70 \%$ of the water holding capacity, which is clearly lower than the optimum for odor and trace gas treatment (Whalen et al., 1990; Bender and Conrad, 1995; Boeckx and Cleemput, 1996). Very high soil water content may impede gas diffusion and thus restrict the supply of $\mathrm{CH}_{4}$ to the methanotrophs. The low solubility of $\mathrm{CH}_{4}$ in water enhances this effect especially at low $\mathrm{CH}_{4}$ concentrations (Bender et Conrad, 1995).

The optimal filter bed water content depends on both the gas flow rate and the type of filter bed (soil, compost or other material employed) (Christophersen et al., 2000). Optimal moisture content of soil materials (from the upper layers of landfills) ideally lies between $13 \%$ and $15.5 \%(\mathrm{wt} / \mathrm{wt})$, on a dry basis (Chiemchaisri et al., 2001b; Jackel et al. 2001; Stein and Hettiaratchi, 2001; Park et al., 2002). For composts or biological residues, optimal bed moisture lies between $25 \%$ and $50 \%(\mathrm{wt} / \mathrm{wt}$ ) (Humer and Lechner, 1999). See Table 1 for a summary of these studies.

\section{$6.4 \mathrm{pH}$}

It is generally suggested that a neutral or slightly acidic medium is maintained for a methane biofilter (Bender and Conrad, 1995). Nikiema et al. (2007) suggested that the $\mathrm{pH}$ of the filter bed is a parameter of less importance because the biodegradation of $\mathrm{CH}_{4}$

Table 1 Optimal water content of Biofilter beds used for methane elimination (Nikiema et al., 2007)

\begin{tabular}{lcl}
\hline Filter bed & $\begin{array}{c}\text { Water content } \\
(\%(w t / w t))\end{array}$ & \multicolumn{1}{c}{ Sources } \\
\hline Compost & $25-50$ & $\begin{array}{l}\text { Humer and Lechner (1999) } \\
\text { Boeckx and Van Cleemput } \\
(1996), \text { Visvanathan et al. }\end{array}$ \\
$\begin{array}{l}\text { Landfill cover } \\
\text { soil }\end{array}$ & $13-30$ & $\begin{array}{l}(1999), \text { Stein and Hettiaratchi } \\
(2001), \text { Giani et al. (2002), Park } \\
\text { et al. (2002) }\end{array}$ \\
Meadow soil & $30-50$ & Wang and Li (2002) \\
Woodland soil & $18-33$ & Wang and Li (2002) \\
Various soils & $11-35$ & $\begin{array}{l}\text { Bender and Conrad (1995), } \\
\text { Christophersen et al. (2000) }\end{array}$ \\
\hline
\end{tabular}


does not generate intermediate or final products capable of significantly influencing the $\mathrm{pH}$. The optimal $\mathrm{pH}$ values for the oxidation of $\mathrm{CH}_{4}$ are in fact the same as those promoting the growth of the majority of methanotrophic bacteria.

According to Hanson and Hanson (1996), methanotrophs are neutrophiles but can tolerate $\mathrm{pH}$ from 5.5 to 8.5. Bender and Conrad (1995) suggested that the optimum $\mathrm{pH}$ ranges between the values of 6.7 and 8.1 for the soil-based filter beds, while Le Mer and Roger (2001) suggested that the range lies between 5 and 6.5 for peat.

\subsection{Filter bed}

The filter bed is the solid phase of the biofilter. A good filter bed provides sufficient space for the development of microorganisms and also has a texture providing a great moisture holding capacity, in addition to appropriate bacteriological and mechanical properties (Nikiema et al., 2007). Various materials that are generally classified as soils, composts, and other materials or combinations, have been used as the filter bed media and tested by researchers (Nikiema et al., 2007). Compost was known as the most efficient filter bed with the Conversion rate $(X)$ ranging from $90 \%$ to $100 \%$. Its conversion rate also varied depending on what materials the compost made from (Hettiaratchi and Stein, 2001; Wilshusen et al., 2004; Haubrichs and Widmann, 2006). In addition, mature compost is more efficient for the biofiltration of $\mathrm{CH}_{4}$ than freshly generated compost (Humer and Lechner, 1999). Soil is another important material for filter bed, and various soils such as agricultural soils, soils derived from mountains, forests and rice plantations, peat bogs and swamps, have also been tested for $\mathrm{CH}_{4}$ biofiltration (Dobbie and Smith, 1996; Hutsch, 1998; Del Grosso et al., 2000). The most effective soils for $\mathrm{CH}_{4}$ elimination are those taken directly from the upper layers of landfill covers with a reported $X$ value of greater than $80 \%$. Usually the filter bed is made by mixing soil with organic materials, such as vegetable residues (beet leaves, wheat straw), clarifier sludges or composts, and this can enhance $\mathrm{CH}_{4}$ elimination (Borjesson et al., 1998; De Visscher et al., 1999; Humer and Lechner 1999; Park et al., 2002). The soils should have appropriate particle size which preferably lies between 0.5 and $2 \mathrm{~mm}$ (Borjesson et al., 1998; Hettiaratchi et al., 2000; Min et al., 2002). When particle sizes are less than $0.02 \mathrm{~mm}$, the bed tends to become packed, preventing the effective diffusion of pollutants in the gas phase and then negatively affecting the conversion (Bender and Conrad, 1995; Le Mer and Roger, 2001; Min et al., 2002). There were also some other synthetic or inert filter materials having been used for $\mathrm{CH}_{4}$ biofiltration. The high $X$ values as more than $95 \%$ were also achieved by using those filter bed materials (Sly et al., 1993; Nikiema et al., 2004b). However, they limited for being used in field scale due to their cost.

\subsection{Nutrients}

Nutrients such as copper, nitrogen and phosphorus are necessary for the growth of microorganisms and therefore are factors that affect the performance of a biofilter (Trotsenko and Khmelenina, 2002). These nutrients are supplied to the microorganisms through the mixture with water that is used to humidify the filter bed (Nikiema et al., 2005).

\subsubsection{Copper}

Copper affects bacterial growth, however, the threshold concentrations have not yet been determined. Hanson and Hanson (1996) demonstrated that while copper inhibits the sMMO enzyme at concentrations above $1 \mu \mathrm{mol} / \mathrm{L}$, it supports the synthesis of the pMMO at concentrations between 1 and $5 \mu \mathrm{mol} / \mathrm{L}$. The $\mathrm{CH}_{4}$ oxidation has been reported to increase by $5 \%$ after adding $0.02 \mathrm{~g} \mathrm{CuCl}_{2}$ per $\mathrm{kg}$ of paddy soil (Mohanty et al., 2000).

\subsubsection{Nitrogen compounds}

Nitrogen is usually provided to microorganisms in inorganic forms: e.g. nitrate $\left(\mathrm{NO}_{3}\right)$, ammonium $\left(\mathrm{NH}_{4}\right)$ or nitrite $\left(\mathrm{NO}_{2}\right)$ ions. Many studies have been performed to determine the effect of each of these compounds on methanotrophs. The sources of $\mathrm{NH}_{4}$ most frequently tested are ammonium chloride, ammonium sulfate and urea. For $\mathrm{NO}_{3}$, sodium nitrate and potassium nitrate are the most studied. On some occasions, ammonium nitrate was used as a nitrogen source (Kightley et al., 1995; Hettiaratchi et al., 2000). No final conclusions on nitrogen effect have been obtained up to now. Some studies reported the improvement on $\mathrm{CH}_{4}$ oxidation by adding some specific nitrogen sources at certain concentrations while others reported different results using same nitrogen sources at similar concentration ranges (Table 2). 
Table 2 Studies of investigating the effect of $\mathrm{N}$ on the work of $\mathrm{CH}_{4}$ biofilters (Nikiema et al., 2007)

\begin{tabular}{|c|c|c|c|}
\hline Sources & Filter beds & $\mathrm{N}$ forms \& Concentration & Effect \\
\hline Hettiaratchi et al. (2000) & Soil & $\begin{array}{l}25 \mathrm{mg} \mathrm{N} / \mathrm{kg} \text { soil in the form of } \mathrm{NH}_{4}^{+} \text {or } \\
\mathrm{NO}_{3}^{-}\end{array}$ & improve $\mathrm{CH}_{4}$ elimination by $100 \%$ \\
\hline Chiemchaisri et al. (2001a) & Soil & $\begin{array}{l}\geqslant 30 \mathrm{mg} \mathrm{N} / \mathrm{kg} \text { soil in the form of } \mathrm{NH}_{4}^{+} \\
\text {or } \mathrm{NO}_{3}{ }^{-}\end{array}$ & Inhibit $\mathrm{CH}_{4}$ elimination \\
\hline $\begin{array}{l}\text { Bronson and Mosier (1994); Cai and Mosier } \\
\text { (2000); Hettiaratchi et al. (2000); Novikov and } \\
\text { Stepanov (2002); Park et al. (2002) }\end{array}$ & & $10-200 \mathrm{mg} \mathrm{N}-\mathrm{NH}_{4}^{+} / \mathrm{kg}$ soil & $\begin{array}{l}\text { Inhibit } \mathrm{CH}_{4} \text { elimination, however, its } \\
\text { extension depends on the type of soil }\end{array}$ \\
\hline \multirow{2}{*}{ Nikiema et al. (2005) } & \multirow{2}{*}{$\begin{array}{l}\text { Inorganic } \\
\text { filter material }\end{array}$} & Sodium nitrate, from 0.14 to $0.75 \mathrm{~g} \mathrm{~N} / \mathrm{L}$ & $\begin{array}{l}5 \text { times increase in the EC (from } 130 \text { to } \\
700 \mathrm{~g} /\left(\mathrm{m}^{2} \cdot \mathrm{d}\right) .\end{array}$ \\
\hline & & Sodium nitrate $>0.75 \mathrm{~g} \mathrm{~N} / \mathrm{L}$ & Decrease the $\mathrm{CH}_{4}$ oxidation \\
\hline $\begin{array}{l}\text { Boeckx and Van Cleemput (1996); Park et al. } \\
(2002)\end{array}$ & Soil & $25-100 \mathrm{mg} \mathrm{N}-\mathrm{NO}_{3}{ }^{-} / \mathrm{kg}^{-}$soil & No $\mathrm{CH}_{4}$ elimination effect \\
\hline Kumaraswamy et al. (2001) & Soil & $2,500 \mathrm{mg} \mathrm{N}-\mathrm{NO}_{3}{ }^{-} / \mathrm{kg}$ soil & Inhibit $\mathrm{CH}_{4}$ elimination \\
\hline
\end{tabular}

The $\mathrm{NH}_{4}^{+}$was considered to have a competition with $\mathrm{CH}_{4}$ when it was provided as a nitrogen source (Mancinelli, 1995; Boeckx and Van Cleemput, 1996; Humer and Lechner, 1999; Sitaula et al., 2000; Novikov and Stepanov, 2002). In addition to oxidizing methane, methanotrophs can convert $\mathrm{NH}_{4}^{+}$to $\mathrm{NO}_{2}^{-}$. Novikov and Stepanov (2002) reported that $12 \%-28 \%$ of the methanotrophic population was dedicated to a nitrification step instead of the $\mathrm{CH}_{4}$ oxidation. The inhibitory effect of $\mathrm{NH}_{4}$ could be minimized if higher $\mathrm{CH}_{4}$ concentrations were continuously provided to the filter media.

While several people reported that $\mathrm{NO}_{3}^{-}$has stronger inhibitory effect on methanotriphs than $\mathrm{NH}_{4}{ }^{+}$, most people suggested that $\mathrm{NO}_{3}{ }^{-}$is the preferred source of fixed nitrogen for methanotrophs (Mancinelli, 1995) and can improve $\mathrm{CH}_{4}$ elimination (Le Mer and Roger, 2001).

\subsubsection{Phosphorus}

Generally speaking, phosphorus is of universal importance in promoting the growth of bacteria. However, few documents have been found in clarifying P effect on $\mathrm{CH}_{4}$ elimination. Several scientists (Kightley et al., 1995; Hettiaratchi et al., 2000; Le Mer and Roger, 2001) reported that the addition of $0.1 \mathrm{~g} \mathrm{P}-\mathrm{K}_{2} \mathrm{HPO}_{4}$ nutrient per $\mathrm{kg}$ soil did not result in any noticeable effect on promoting $\mathrm{CH}_{4}$ elimination. Thus, the role of phosphorus in $\mathrm{CH}_{4}$ elimination remains unclear and further investigations would be needed (Nikiema et al., 2007).

\subsubsection{Other elements}

Potassium sulfate and manganese oxide have been reported to increase the oxidation of $\mathrm{CH}_{4}$ (Kumaras- wamy et al., 2001), while the excessive concentrations of sodium chloride and potassium chloride were reported to be $\mathrm{CH}_{4}$ elimination inhibitors (Cai and Yan, 1999; Kravchenko, 2002; Gebert et al., 2003).

\section{Empty bed residence time (EBRT)}

Biofilters have been developed and operated for landfill gas treatment at various methane inlet concentrations up to $260 \mathrm{~g} / \mathrm{m}^{3}(40 \%, \mathrm{v} / \mathrm{v})$ at empty bed air residence times (EBRT) between $5 \mathrm{~min}$ and $5 \mathrm{~h}$, whereas typical EBRT is $25 \mathrm{~s}$ to over a minute for common biofilter applications (Melse and Van De Werf, 2005).

Biological conversion of methane in a biofilter is a slow process due to the low water solubility of methane (Henry's law constant is $1.5 \times 10^{-3} \mathrm{M} / \mathrm{atm}$ ), and this is why such long EBRT are applied. Previous work by Streese and Stegmann (2003) showed first-order removal kinetics for methane inlet concentrations up to $16 \mathrm{~g} \mathrm{CH}_{4} / \mathrm{m}^{3}$ in an operated biofilter.

\section{Conclusions}

For covered liquid manure storage, the methane concentration in the headspace varied depending on the sealed condition of the headspace. In theory, the headspace concentration equals undiluted biogas that contains about $425 \mathrm{~g} / \mathrm{m}^{3}(65 \%, \mathrm{v} / \mathrm{v})$ if the headspace is completely sealed. In practice, however, the cover seldom completely airtight, which results in methane concentrations ranging from 0.1 to $20 \mathrm{~g} / \mathrm{m}^{3}$ ? Biofiltration is one of the promising techniques that are capable of reducing $80 \%$ of $\mathrm{CH}_{4}$ emissions from manure storage. The $\mathrm{CH}_{4}$ removal efficiency is influenced by many factors, including $\mathrm{CH}_{4}$ and $\mathrm{O}_{2}$ concentrations, 
temperature, moisture, composition of the filter bed, nutrient, empty bed residency time (EBRT). Biological conversion of methane in a biofilter is a slow process due to the low water solubility of methane. The residence times (EBRT) between $5 \mathrm{~min}$ and $5 \mathrm{~h}$ have been used, whereas a typical EBRT of $25 \mathrm{~s}$ is used for common biofilter applications. The temperature in which methanotrophic bacteria are active ranges from $10^{\circ} \mathrm{C}$ to $45^{\circ} \mathrm{C}$. The maximum activity was found at around $30^{\circ} \mathrm{C}$. The optimal water content of filter bed depends on both the gas flow rate and the type of filter

\section{References}

Acha V, Alba J, Thalasso F. 2002. The absolute requirement for carbon dioxide for aerobic methane oxidation by a methanotrophic-heterotrophic soil community of bacteria. Biotechnology Letter, 24(9): 675-679.

Auman A J, Lidstrom M E. 2002. Analysis of sMMO containing type I methanotrophs in Lake Washington sediment. Environmental Microbiology, 4(9): 517-524

Bender M, Conrad R. 1994. Methane oxidation activity in various soils and freshwater sediments-occurrence, characteristics, vertical profiles, and distribution on grain size fractions. Journal of Geophysical Research-Atmospheres, 99(D8): 16531-16540.

Bender M, Conrad R. 1995. Effect of $\mathrm{CH}_{4}$ concentrations and soil conditions on the induction of $\mathrm{CH}_{4}$ oxidation activity. Soil Biology and Biochemistry, 27(12): 1517-1527.

Bodelier P L E, Frenzel P. 1999. Contribution of methanotrophic and nitrifying bacteria to $\mathrm{CH}_{4}$ and $\mathrm{NH}_{4}$ oxidation in the rhizosphere of rice plants as determined by new methods of discrimination. Applied and Environmental Microbiology, 65(5): 1826-1833.

Boeckx P, Van Cleemput O. 1996. Methane oxidation in a neutral landfill cover soil-influence of moisture content, temperature, and nitrogen-turnover. Journal of Environmental Quality, 25(1): 178-183.

Boeckx P, Van Cleemput O. 2000. Methane oxidation in landfill cover soils. In: Singh S N. Trace Gas Emissions and Plants. The Netherlands: Kluwer Academic Publishers, 197-213.

Borjesson G, Sundh I, Tunlid A, et al. 1998. Microbial oxidation of $\mathrm{CH}_{4}$ at high partial pressures in an organic landfill cover soil under different moisture regimes. FEMS Microbiology Ecology, 26(3): 207-217.

Bronson K F, Mosier A R. 1994. Suppression of methane oxidation in aerobic soil by nitrogen fertilizers, nitrification inhibitors, and urease inhibitors. Biology and Fertility of Soils, 17: 263-268.

Cai Z C, Mosier A R. 2000. Effect of $\mathrm{NH}_{4} \mathrm{Cl}$ addition on methane oxidation by paddy soils. Soil Biology and Biochemistry, 32(11/12): 1537-1545.

Cai Z C, Yan X Y. 1999. Kinetic model for methane oxidation by paddy soil as affected by temperature, moisture and $\mathrm{N}$ addition. Soil Biology and Biochemistry, 31(5): 715-725. bed (soil, compost or other material employed) and ranges from $30 \%-70 \%$ of the water holding capacity. Compost is the best material for filter bed. The optimal $\mathrm{pH}$ for methanotrophic bacteria is neutral to slightly acidic. Copper and nitrogen compounds, especially nitrate, are reported as important nutrients to methanotrophic bacteria but their optimal concentrations have not been found. Phosphorus and other elements such as potassium and manganese were reported to affect the performance of methanotrophic bacteria but need to further confirmation.

Chiemchaisri W, Visvanathan C, Wu J S. 2001a. Biological activities of methane oxidation in tropical landfill cover soils. Journal of Solid Waste Technology and Management, 27(3-4): 129-136.

Chiemchaisri W, Wu J S, Visvanathan C. 2001b. Methanotrophic production of extracellular polysaccharide in landfill cover soils. Water Science and Technology, 43(6): 151-159.

Christophersen M, Kjeldsen P. 2001. Lateral gas transport in soil adjacent to an old landfill: factors governing gas migration. Waste Management \& Research, 19(6): 579-594.

Christophersen M, Linderod L, Jensen P E, et al. 2000. Methane oxidation at low temperatures in soil exposed to landfill gas. Journal of Environmental Quality, 29(6): 1989-1997.

Cole C V, Duxbury J, Freney J, et al. 1997. Global estimates of potential mitigation of greenhouse gas emissions by agriculture. Nutrient $\mathrm{Cy}-$ cling in Agroecosystems, 49: 221-228.

Czepiel P M, Mosher B, Crill P M, et al. 1996. Quantifying the effect of oxidation on landfill methane emissions. Journal of Geophysical Research-Atmospheres, 101(D11): 16721-16729.

Dammann B, Streese J, Stegmann R. 1999. Microbial oxidation of methane from landfills in biofilters. In: Proceedings of Sardinia 99, 7th International Waste Management and Landfill Symposium, S. Margherita di Pula, Cagliari, Italy, 4-9 October 1999, USA: SWANA-Solid Waste Association of North America, 517-524.

De Visscher A, Thomas D, Boeckx P, et al. 1999. Methane oxidation in simulated landfill cover soil environments. Environmental Science and Technology, 33(11): 1854-1859.

Del Grosso S J, Parton W J, Mosier A R, et al. 2000. General $\mathrm{CH}_{4}$ oxidation model and comparisons of $\mathrm{CH}_{4}$ oxidation in natural and managed systems. Global Biogeochemical Cycles, 14(4): 999-1019.

DeSutter T M, Ham J M. 2005. Lagoon-Biogas emissions and carbon balance estimates of a swine production facility. Journal of Environmental Quality, 34: 198-206.

Dobbie K E, Smith K A. 1996. Comparison of $\mathrm{CH}_{4}$ oxidation rates in woodland, arable and sand aside soils. Soil Biology and Biochemistry, 28(10-11): 1357-1365.

Du Plessis C A, Strauss J M, Sebapalo E M T, et al. 2003. Empirical 
model for methane oxidation using a composted pine bark biofilter. Fuel, 82: 1359-1365.

Erwin D P, Erickson I K, Delwiche M E, et al. 2005. Diversity of oxygenase genes from methane- and ammonia-oxidizing bacteria in the Eastern Snake River Plain aquifer. Applied Environmental Microbiology, 71(4): 2016-2025.

Gebert J, Groengroeft A, Miehlich G. 2001. Microbial reduction of methane and trace gas emissions in a biofilter. In: Proceedings from the 8th International Waste Management and Landfill Symposium, S Margherita di Pula, Cagliari, Italy, 1-5 October 2001. USA: SWANA-Solid Waste Association of North America, Silver Spring, 585-593.

Gebert J, Groengroeft A, Miehlich G. 2003. Kinetics of microbial landfill methane oxidation in biofilter. Waste Management, 23: 609-619.

Gebert J, Groengroeft A. 2006a. Passive landfill gas emission-influence of atmospheric pressure and implications for the operation of methane-oxidizing biofilters. Waste Management, 26: 245-251.

Gebert J, Groengroeft A. 2006b. Performance of a passively vented field-scale biofilter for the microbial oxidation of landfill methane. Waste Management, 26: 399-407.

Hanson R S, Hanson T E. 1996. Methanotrophic bacteria. Microbiological Reviews, 60(2): 439-471.

Haubrichs R, Widmann R. 2006. Evaluation of aerated biofilter systems for microbial methane oxidation of poor landfill gas. Waste Management, 26: 408-416.

Henckel T, Roslev P, Conrad R. 2000. Effects of $\mathrm{O}_{2}$ and $\mathrm{CH}_{4}$ on presence and activity of the indigenous methanotrophic community in rice field soil. Environmental Microbiology, 2(6): 666-679.

Hettiaratchi J P A, Stein V B, Achari G. 2000. Biofiltration: a cost-effective technique for controlling methane emissions from sub-surface sources. In: Balkema A A. Sixth Environmental Issues and Management of Waste in Energy and Mineral Production, Rotterdam, 291-299.

Hettiaratchi J P A, Stein V B. 2001. Methanobiofilters (MBFs) and landfill cover systems for $\mathrm{CH}_{4}$ emission mitigation. In: Proceedings of the 17th International Conference on Solid Waste Technology and Management, Philadelphia, PA, Oct. 20-24, 2001. USA: Journal of Solid Waste Technology Management, 465-476.

Humer M, Lechner P. 1999. Alternative approach to the elimination of greenhouse gases from old landfills. Waste Management Research, 17(6): 443-452.

Hutsch B W. 1998. Tillage and land use effects on methane oxidation rates and their vertical profiles in soil. Biology and Fertility of Soil, 27: 284-292.

Jackel U, Schnell S, Conrad R. 2001. Effect of moisture, texture and aggregate size of paddy soil on production and consumption of $\mathrm{CH}_{4}$. Soil Biology and Biochemistry, 33(7-8): 965-971.

Kightley D, Nedwell D B, Cooper M. 1995. Capacity for methane oxidation in landfill cover soils measured in laboratory-scale soil microcosms. Applied Environmental Microbiology, 61(2): 592-601.
Kjeldsen P, Dalager A, Broholm K. 1997. Attenuation of methane and nonmethane organic compounds in landfill gas affected soils. Journal of Air Waste Management Association, 47(12): 1268-1275.

Kravchenko I K. 2002. Methane oxidation in boreal peat soils treated with various nitrogen compounds. Plant and Soil, 242(1): 157-162.

Kumaraswamy S, Ramakrishnan B, Sethunathan N. 2001. Methane production and oxidation in an anoxic rice soil as influenced by inorganic redox species. Journal of Environmental Quality, 30(6): 2195-2201.

Le Mer J, Roger P. 2001. Production, oxidation, emission and consumption of methane by soils: a review. European Journal of Soil Biology, 37(1): 25-50.

Li G W, Hu H Y, Hao J M, et al. 2002. Use of biological activated carbon to treat mixed gas of toluene and benzene in biofilter. Environmental Technology, 23: 467-477.

Mancinelli R L. 1995. The regulation of methane oxidation in soil. Annual Review of Microbiology, 49: 581-605.

Melse W R, Van De Werf W A. 2005. Biofiltration for mitigation of methane emission from animal husbandry. Environmental Science and Technology, 39: 5460-5468.

Massié D. 2006. Final Rreport of Greenhouse Gas Mitigation Program Demonstration and Communication Project. Ottawa, Canada. Canadian Pork Council.

Min H, Chen Z Y, Wu W X, et al. 2002. Microbial aerobic oxidation of methane in paddy soil. Nutrient Cycling in Agroecosystems, 64(1-2): 79-85.

Mohanty R S, Bharati K, Deepa N, et al. 2000. Influence of heavy metals on methane oxidation in tropical rice soils. Ecotoxicology and Environmental Safety, 47: 277-284.

Mor S, De Visscher A, Ravindra K, et al. 2006. Induction of enhanced methane oxidation in compost: temperature and moisture responses. Waste Management, 26(4): 381-388.

Nikiema J, Bibeau L, Lavoie J, et al. 2004. Biogas, a real problem: Biofiltration, a promising solution. In: Proceedings of the USCCSC-TRG Conference on Biofiltration, Los Angeles, California. October 20-22. 73-80.

Nikiema J, Bibeau L, Lavoie J, et al. 2005. Biofiltration of methane: an experimental study. Chemical Engineering Journal, 113(2-3): 111-117.

Nikiema J, Brzezinski R, Heitz M. 2007. Elimination of methane generated from landfills by biofiltration: a review. Reviews in Environmental Science and Biotechnology, 6: 261-284.

Novikov V V, Stepanov A L. 2002. Coupling of microbial processes of methane and ammonium oxidation in soils. Microbiology, 71(2): 234-237.

Nozhevnikova A N, Lifshitz A B, Lebedev V S, et al. 1993. Emission of methane into the atmosphere from landfills in the former USSR. Chemosphere, 26(1-4): 401-417.

Nozhevnikova A N, Nekrasova V K, Kevbrina M V, et al. 2001. Production and oxidation of methane at low temperature by the micro- 
bial population of municipal sludge checks situated in northeast Europe. Water Science and Technology, 44(4): 89-95.

Park S, Brown K W, Thomas J C. 2002. The effect of various environmental and design parameters on methane oxidation in a model biofilter. Waste Management Research, 20(5): 434-444.

Patty E, Trzcinski K M, Desjardins L R. 2005. Quantifying the reduction of greenhouse gas emissions as a result of composting dairy and beef cattle manure. Nutrient Cycling in Agroecosystems, 72: 173-187.

Roland W Melse, Arjan W, van der Werf. 2005. Biofiltration for mitigation of methane emission from animal husbandry. Environmental Science and Technology, 39 (14): 5460-5468.

Safley L M, Westerman P W. 1988. Biogas production from anaerobic lagoons. Biological Wastes, 23: 181-193.

Safley L M, Westerman P W. 1989. Anaerobic lagoon biogas recovery system. Biological Wastes, 27: 43-62.

Sharpe R R, Harper A L. 1999. Methane emissions from an anaerobic swine lagoon. Atmospheric Environment, 33: 3627-3633.

Sitaula B K, Hansen S, Sitaula J I B, et al. 2000. Methane oxidation potentials and fluxes in agricultural soil: effects of fertilization and soil compaction. Biogeochemistry, 48(3): 323-339.

Sly L I, Bryant L J, Cox J M, et al. 1993. Development of a biofilter for the removal of methane from coal mine ventilation atmospheres. Applied Microbiology Biotechnology, 39(3): 400-404.

Stein V B, Hettiaratchi J P A. 2001. Methane oxidation in three Alberta soils: influence of soil parameters and methane flux rates. Environmental Technology, 22(1): 101-111.

Stein V B, Hettiaratchi J P A, Achari G. 2001. Numerical model for biological oxidation and migration of methane in soils, practice periodical of hazardous. Toxic, and Radioactive Waste Management, 5(4): 173-235.

Straka F, Crha J, Musilova M, et al. 1999. LFGBiofilters on old landfills. In: Proceedings of Sardinia 99, 7th International Waste Management and Landfill Symposium, S Margherita di Pula, Cagliari, Italy, 4-9 October 1999, USA: SWANA-Solid Waste Association of North America, 507-516.

Streese J, Dammann B, Stegmann R. 2001. Reduction of methane and trace gas emissions from former landfills in biofilters. In: Proceedings Sardinia 2001, 8th International Waste Management and Landfill Symposium. Vol. 2. CISA, Cagliari, Italy, 575-584.

Streese J, Stegmann R. 2003. Microbial oxidation of methane from old landfills in biofilters. Waste Management, 23: 573-580.

Summerfeld R A, Mosier A R, Musselman R C. 1993. $\mathrm{CO}_{2}, \mathrm{CH}_{4}$ and $\mathrm{N}_{2} \mathrm{O}$ flux through a Wyoming snowpack and implications for global budgets. Nature, 361: 140-142.

Tahraoui K, Denis R. 1998. Biodegradation of BTX vapors in a compost medium biofilter, Compost Science and Utilization, 6(2): 13-21.

Trotsenko Y A, Khmelenina V N. 2002. Biology of extremophilic and extremotolerant methanotrophs. Archives of Microbiology, 177(2): 123-131.

Venugopal S, Chandrakanthi M, Hettiaratchi P. 2004. Application of methanotrophic biofilters (mbfs) in treating methane $\left(\mathrm{CH}_{4}\right)$ emissions from oil and gas industry. Research report, TransCanada PipeLines Ltd.

Wagner-Riddle C, Park H K, Thurtell W G. 2006. A micrometeorological mass balance approach for greenhouse gas flux measurements from stored animal manure. Agriculture and Forest Meteorology, 136: 175-187.

Wang M X, Li J. 2002. $\mathrm{CH}_{4}$ emission and oxidation in Chinese rice paddies. Nutrient Cycling Agroecosystems, 64: 43-55.

Whalen S C, Reeburgh W S, Sandbeck K A. 1990. Rapid methane oxidation in a landfill cover soil. Applied Environmental Microbiology, 56: 3405-3411.

Whalen S C, Reeburgh W S. 1996. Moisture and temperature sensitivity of $\mathrm{CH}_{4}$ oxidation in boreal soils. Soil Biology and Biochemistry, 28(10): 1271-1281.

Wilshusen J H, Hettiaratchi J P A, Stein V B. 2004. Longterm behavior of passively aerated compost, methanotrophic biofilter columns. Waste Management, 24(7): 643-653.

Yoon I, Park C. 2002. Effects of gas flow rate, inlet concentration and temperature on biofiltration of volatile organic compounds in a peat-packed biofilter. Journals of Bioscience and Bioengineering, 93(2): 165-169. 